\title{
SOLUTIONS TO RESTRUCTURING THE NETWORK OF TEACHER TRAINING INSTITUTIONS IN VIETNAM
}

\section{Quang Hong Pham 1 , Nam Danh Nguyen ${ }^{2,+}$}

\author{
Article History \\ Received: January 12, 2020 \\ Accepted: February 26, 2020 \\ Published: March 30, 2020
}

\author{
Keywords \\ Systematising, teacher \\ education, pedagogical \\ university, teacher training
}

\author{
${ }^{1}$ Thai Nguyen University, Vietnam; \\ ${ }^{2}$ Thai Nguyen University of Education, Vietnam \\ ${ }^{+}$Corresponding author •Email: danhnam.nguyen@dhsptn.edu.vn
}

\section{INTRODUCTION}

In developed countries, pedagogical institutions are built and structured within a comprehensive university while in Vietnam, there are teacher training institutions ranging from vocational colleges to universities. Meanwhile, the teacher training management system has transformed from centralized management, assigned enrollment quotas and assigned jobs for graduates to universities' autonomy to determine their own targets according to training capacity and pedagogy graduates seeking their own employment. This has created more autonomy for pedagogical universities and colleges to participate in teacher training but simultaneously caused difficulties in controlling and balancing the number of graduates as well as unequal levels and qualities of training among institutions.

Besides, it is suggested that it is important to improve the quality of teacher education and upgrade pedagogical colleges in order to create fair competition according to the market mechanism (Pham Hong Quang, 2013). The competitiveness and autonomy of universities can generally impact pedagogical universities and colleges in a more liberal way, leading to too wide fluctuations in the scope and quality of teacher training (Pham Hong Quang, 2011\&2013). Therefore, it is essential to systematising teacher training institutions in the present context.

This paper presents an overview of systematising teacher training institutions in several countries and examine the limitations of the Vietnamese system. Accordingly, some solutions are proposed to restructure the network of pedagogical universities in Vietnam.

\section{LITERATURE REVIEW}

In order to direct the development of the higher education system, some countries have conducted a national development plan for higher education with a focus on planning the network of tertiary education institutions. For developed countries with considerable university autonomy, several states have designed master plans for higher education development, for example California, Connecticut and Pennsylvania in the US and Western Australia in Australia (Adele Gordon, 2009; Paul R. Weldon, 2015).

In many countries around the world, teacher education observes the market mechanism and the needs of the labor market. However, due to the unique characteristics of each country, there are differences in the role and intervention of the State in the teacher education system. Some countries still maintain centralized management of the teacher education system such as South Korea, Singapore, France, Netherlands, England, China, Japan and Hong Kong (Lee, 2000). In these countries, the Ministry of Education manages almost every aspect of the training process and issues diplomas/ certificates to teachers. Meanwhile, some countries have granted full autonomy to higher education institutions in training teachers such as the United States, Germany, Australia and Finland (Adele Gordon, 2009).

In France, the state's over-centralized management has led to a lack of autonomy in training institutions. In 1989, France transformed teacher training from a network of pedagogical universities into teacher training institutes. By 2008, these institutes had been transformed into faculties of teacher education within universities. In the Netherlands, the Ministry of Education provides guidelines, regulations and instructions for applying recruitment requirements, graduate standards and content of teacher training programs. The compliance with these regulations is controlled by the 
Inspection Department. In the United Kingdom, the Department of Teacher Training, the Department of Education and Skills, the British Education Standards and Teaching Council are responsible for training and issuing degrees/ certificates for teachers at all levels. These agencies are responsible for developing and issuing regulations on the training process and certification for teachers, based on a set of standards for teacher education program accreditation, enrollment and graduate requirements, teacher certification examinations and teacher education curricula. In Taiwan, there are only few teacher training institutions that calculate thoroughly their annual teacher training quotas and guarantee future jobs for their graduates in accordance with their training majors (Adele Gordon, 2009). Previously, the Chinese teacher training system was limited to single-subject training and its low quality could not meet the social needs. China is currently taking measures to enhance the position of pedagogy and teaching career such as investing resources in six key pedagogical universities, renovating the university governance system towards increasing autonomy and sharing resources of pedagogical universities, renovating teacher education programs, enhancing university and curriculum standards, restructuring pedagogical universities and strengthening in-service teacher training (Paine, L.W. et al., 2006).

In Vietnam, there are 235 universities in which 170 are state-owned, 60 are private and 5 are 100\% foreign invested. 58 of these universities are either pedagogical or multi-disciplinary with teacher education. In the field of teacher education, there are currently 14 pedagogical universities, 33 pedagogical colleges in localities and 33 faculties of education in other multidisciplinary institutions. In addition, 24 colleges and 38 schools are not pedagogical institutions but are training teachers. Together with the socio-economic transition from centralized and subsidized mechanism into market mechanism with macro-regulation, tertiary education should also experience corresponding changes.

The higher education system must undertake the training of manpower not only for the State but also for many other economic sectors. Order-based training of human resources means most training products should be highly adaptable to the labor market (Nguyen Thi Binh, 2013; Pham Quang Sang, 2011), and training for teacher resources also follows the same trend. The problem is that teacher training should obey the order-based mechanism or adapt to the economic development under the socialist-oriented market mechanism. If it is the case of order-based mechanism, pedagogical graduates should be assigned with appropriate jobs. Therefore, it is clear that teacher education must adapt to the development of a market economy, has diversified teacher training models and meet different local needs. However, the scale of teacher training is unique because of periodical changes due to retired teachers, changes in population size, renovations of education and training as well as of teacher policies and so on. Therefore, predictive research on the training needs for teaching resources is an urgent requirement to restructure the network of pedagogical universities in Vietnam.

\section{METHODS AND RESULTS}

\subsection{Research methods}

In this study, we used practical research methods and examined international experiences focusing on Chinese model of structuring teacher training universities. From October 2018 to October 2019, we conducted field surveys with questionnaires at 17 universities and pedagogical colleges throughout the country, held 17 seminars and 3 scientific workshop, carried out structured interviews with 60 administrators and lecturers and in-depth interviews with 12 rectors of some key pedagogical universities across the country. The questionnaire system was coded into levels ranging from 'strongly agree' to 'strongly disagree'. In-depth interviews were recorded and notes were taken to generalize into views and restructuring principles of educational experts.

\subsection{Research results}

\subsubsection{The limitations and inadequacies of the teacher training system in Vietnam}

Because pedagogical universities in Vietnam is mainly under the public system, the scattered investment has made no breakthrough in the development of teacher training facilities. In fact, in response to challenging entrance admissions, some localities have recently proposed solutions by merging the pedagogical college into the faculty of education within another university in the same region. However, this is just a situational approach. The Prime Minister issued Decision No.121/2007/QĐ-TTg approving "Planning the network of Vietnamese universities and colleges in the 2006-2020 period" (Prime Minister, 2007) and Decision No.37/2013/QĐ-TTg on "Adjusting the planning of Vietnam university and college network in the 2006-2020 period" (hereinafter referred to as Planning 37) (Prime Minister, 2013). In terms of enrollment targets according to Planning 37, by 2020 the teacher training sector will account for $10 \%$ of the total number of around 560,000 newly recruited students. However, from 2013 up to now, enrollment targets of this sector have always been higher than the set targets. The results of this statistical, analytical and predictive research show that in recent years, pedagogical universities have been recruiting massively 
and lacking control over the requirements and quality of training, wasting the State budget. The process of restructuring the university network according to Planning 37 has revealed some following limitations:

(1) The distribution of higher education institutions is too geographically spread; the establishment of universities still address the developmental needs of individual ministries, branches or localities, rather than the uniformity and synchronism of the whole system;

(2) The quality of training is not commensurate with the increasing quantity: universities were established and upgraded at an increasingly high speed from 2007 to 2011. According to Planning 37, it has exceeded the target while lacking control over quality assurance factors as well as lacking supply and demand forecasts have led to the situation that many graduates are unable to find jobs, which entails an imbalance between supply and demand of teaching resources. Many pedagogical universities have yet to focus on training conditions that could meet enrollment scale; lecturers have not yet met the qualification requirements; financial resources are scattered; market forecasts have not yet been implemented, causing training branches within a region to be overlapped.

Moreover, teacher training institutions have not been systematic, nor have they been connected, supported and put in hierarchy. Basically, the universities operate independently where teacher training components are arranged side by side.

The above limitations are due to the following causes:

(i) The ability to forecast labor supply and demand at the national and institutional level is limited and has not been taken seriously. There is still a lack of an information system of higher education management that can collect, analyze and disclose information from higher education and teacher training institutions.

(ii) Investment in qualified conditions does not correspond to the increasing number of higher education institutions. For a long time, most localities wished to establish universities in order to meet the growing needs of human resource in the area. However, when establishing a new university, many localities, ministries, and investors did not have serious scientific calculations and surveys on financial capacity, training needs, regional connectivity, and the movement of labor force among localities.

(iii) Planning focuses on quantity and geographic space rather than on the development of high-quality staff and the use of quality assurance tools.

(iv) Planning management is not focusing on the use of quality management tools while planning implementation is not adequately supervised and inspected. The approach to developing Planning 37 is mainly based on quantitative and spatial planning indicators rather than the application of well-qualified planning tools.

This situation leads to a number of paradoxes in teacher training: (i) the number of enrollment is inversely proportional to the needs and disproportionate across regions; (ii) although there are pedagogical universities which are managed by the Ministry of Education and Training in some localities and able to meet the needs for teachers at all levels, pedagogical colleges which are locally controlled still exist; (iii) in many localities where pedagogical colleges are still assigned with annual enrollment quotas, recruitment notices for school teachers only feature those with university diplomas Obviously, some provinces have no demand for college graduates but still maintain this teacher training system.

\subsubsection{Objectives and roadmap of restructuring the network of pedagogical universities in Vietnam}

Restructuring the network of pedagogical universities generally aims to form a network of teacher training and retraining to ensure leanness, quality, and efficiency, reasonable quantity and structure. This network will include a number of key pedagogical universities as well as branches of pedagogical universities and teacher education institutions in localities; closely linking training and demands on the number, structure, and capacity of teachers of the localities. In details, the first objective of the restructuring is to meet the needs of teacher training in accordance with the educational development goals at local and national levels, balancing the number of local teachers and the training of different majors. Secondly, restructuring is to enhance the efficiency of the investment, allocation and use of investment budget for lecturers' competence development. The plan aims to limit the small-scale and fragmented development of some teacher training institutions and restrict scattered and wasteful investment of the state budget. Thirdly, the plan aims to create a clear stratification and classification in the system of teacher training institutions based on the training mission and quality, limiting overlaps and inefficiencies and meeting the requirements of the labor market in a new context.

According to the survey on 60 experts of pedagogical universities, $100 \%$ of respondents agreed that planning of the network of pedagogical universities should consider geopolitical, socio-economic and cultural factors of each region. In particular, it is necessary to closely link the teacher training process with the social requirement of using the teacher resource, paying attention to the "market area" factor, the attractiveness and the "influence" of some key 
pedagogical universities. In addition, restructuring should also take into account the context of fundamental and comprehensive renovation in education and training, the context of international integration, the world's new trends in teacher training and changes in personality model of future teachers.

The roadmap for implementing the plan for the period 2020-2025 is to establish two key pedagogical universities in Hanoi and Ho Chi Minh City on the basis of reorganizing Hanoi National University of Education and Ho Chi Minh City University of Education and some other pedagogical universities/ colleges in the same region. It also includes building a "satellite" network of teacher training institutions in localities on the basis of merging and reorganizing pedagogical colleges and faculties of education in multidisciplinary universities. In the period of 2026-2030, one more key pedagogical university will be established in the central region on the basis of reorganizing pedagogical universities in the area and a number of neighboring provinces and cities. Besides, there should be at least one key pedagogical university ranked in the world's top 1,000 best universities or the top 500 best universities in Asia in the field of education.

The above plan is also consistent with the opinions of many expert participants in the survey, with $75 \%$ of the respondents claiming the necessity to establish three key pedagogical universities (one in the north, one in the central region and one in the south) and continue to develop from three to five other pedagogical universities; $16.7 \%$ of them supported the plan to form 04 key pedagogical universities (one in the north, one in the central region, one in the south and one in ethnic minority areas) and continue to develop from two to four other pedagogical universities; and only $8.3 \%$ of them chose to set up two key pedagogical universities (one in the north and one in the south) and continue to develop from three to five other pedagogical universities. According to some experts, it is necessary to build a spreading relationship from key universities to other "satellite" pedagogical universities where bilateral cooperation and equality for mutual development are prioritized. In the restructuring process, it is necessary to inherit international experience in university modeling and networking, creating a legal corridor to recognize each other's credits and subjects and share resources, facilitating the exchange between students and lecturers. In particular, it is essential to clearly define the functions and tasks of key as well as other 'satellite' pedagogical universities. Key pedagogical universities must preside over new fundamental issues of education, support and coordinate with other pedagogical universities in performing highquality training tasks. Meanwhile, satellite pedagogical universities and colleges carry out specific tasks at local level.

\subsubsection{Solutions to restructuring the teacher training system in Vietnam}

Basing on results of international experience research, surveys at universities, pedagogical colleges and interviews with educational experts in Vietnam, we propose some following solutions:

- State management: Develop pedagogical university standards, teacher education programs and guidelines for standards-based assessment; review and evaluate the system of legal documents; propose amendments, supplements, replacements and perfecting regulations and policies to support pedagogical universities in legally exercising autonomy and accountability; forecast teachers' needs of localities, accordingly assigning appropriate quotas for each teacher education institution; control the quality of teacher training and retraining courses of educational institutions; increase inspection and supervision on the implementation of training and retraining courses for teachers as well as educational management staff.

- Quality assurance: Promote quality accreditation of teacher training institutions, teacher training programs, and proceed to assign annual training targets to teacher training institutions that meet quality requirements; develop quality assurance centers in pedagogical universities; develop and implement an investment plan on key pedagogical universities to promote international integration; reform university governance, enhance autonomy and accountability of teacher training institutions along with effective management and monitoring mechanisms; enhance the application of information technology and advanced technology, the application of international standards in the management of training and scientific research activities; invest in building facilities and modern equipment for teacher training institutions, ensuring an effective use and exploitation of high-quality teaching and learning conditions; promote connection between the network of pedagogical universities and the system of educational institutions at all levels and localities to ensure standardization of teacher qualifications and educational management staff.

- Lecturers' competence development: Promote the training and retraining of lecturers and managers at pedagogical universities; teacher training institutions to meet the quantity and quality assurance standards; regularly assess and classify the quality of teaching staff to promptly adjust training and retraining policies; continue to implement training and retraining activities for teachers and educational managers; develop teacher training programs to ensure that teacher resources at all levels meet the standards prescribed in Education Law 2019; continue to support institutions in training teaching staff domestically and internationally to achieve doctoral degrees; prioritize pedagogical teachers' training for doctoral degrees in educational sciences abroad; coordinate with related parties to 
revise policies on detecting, fostering, using and promoting teachers, providing special regimes for lecturers and educational administrators, offering payment according to efficiency and position; promote the attraction of leading experts at home and abroad to participate in research programs and projects, and teacher training programs at pedagogical universities; establish the Association of Teachers and Educational Managers which consults and support the development of mechanisms and policies in teacher education.

- Financial issues: Focus on investment in developing material facilities, teaching equipment, learning materials and the potential of science and technology; develop key pedagogical universities to perform the leading role in the teacher training system; promote the attraction of people's and foreign capital for teacher training activities. Regarding this solution, educational experts said that "It is necessary to develop regulations and coordination mechanisms between key pedagogical universities and other pedagogical institutions with Department of Home Affairs and Department of Education and Training to standardize and improve the competences of teachers and educational administrators; forecast recruitment needs as a basis for developing enrollment criteria; improve competences and promote the development of pedagogical universities; coordinate to ensure the quality of teacher training and the transfer of scientific research results. In addition, localities control the administration and, finance of local universities while professional activities are assigned to pedagogical institutions".

\section{DISCUSSION AND CONCLUSION}

In the context of globalization and integration, teachers are required to meet national as well as new international professional standards to be able to adapt to a new working environment. Therefore, pedagogical universities need to train teachers with the capacity to teach multi-models, improve the quality of training teachers and educational managers for schools. At the same time, it is essential to restructure the network of pedagogical universities in Vietnam to identify key investments and avoid scattered and wasteful investments in teacher education. In order to implement this plan, pedagogical universities need to conduct self-assessments against standards and teacher education program accreditation according to national and international standards. In addition, they should proactively restructure themselves, renovate the governance on the basis of autonomy and seriously implemented accountability; renovate training programs; strengthen the interconnection in training; diversify training models and approaches; improve the quality of teachers and management staff; strengthen conditions for quality assurance and gradually improve the quality of training, scientific research and community service.

Acknowledgments: This paper is supported by a research grant from the National Educational Science Program coded KHGD/16-20 entitled "Research on restructuring the network of teacher training institutions in Vietnam up to 2025 , a vision until 2035 ”.

\section{REFERENCES}

Adele Gordon (2009). Restructuring teacher education. Issues in Education Policy, Number 6, Centre for Education Policy Development.

Lee Jeong-Kyu (2000). Main reform on higher education systems in Korea. Revista Electrónica de Investigación Educativa, 2(2), 61-76.

Paine, L.W., Fang, Y.P., Wilson, S. (2006). Reform as a hybrid model of teaching and teacher development in China. International Journal for Education Research, 45(4-5), 279-289.

Paul R. Weldon (2015). The teacher workforce in Australia: Supply, demand, and data issues. Australia Council for Educational Research, Policy Insights, Issue 2, Melbourne: ACER.

Pham Hong Quang (2013). Developing teacher training curriculum: Theory and practice. Thai Nguyen University Publishing House.

Prime Minister (2007). Decision No.121/2007/QĐ-TTg on the approval of "Planning on the network of Vietnamese universities and colleges in the 2006-2020 period" (issued on July 27, 2007).

Prime Minister (2013). Decision No.37/2013/QĐ-TTg on "Adjusting the planning of Vietnam university and college network 2006-2020" (issued on June 26, 2013).

Pham Quang Sang (2011). Research on building the predictive model to develop tertiary education in Vietnam. Research Project at Ministerial Level, code: B20078-37-31TĐ, The Vietnam National Institute of Educational Sciences.

Nguyen Thi Binh (2013). Research on proposing some measures of renovation in training and fostering teachers. Research Project at National Level, Vietnam Peace and Development Foundation. 